\title{
Assessment of Health Information System Change Resistance
}

Alaattin PARLAKKILIÇ, Ufuk University, Management Information Systems Department, Assoc.Prof., alaattin.parlakkilic@ufuk.edu.tr, (D) 0000-0002-6834-6839

Nevzat ÜNALAN, Ufuk University, Vocational School, Assist. Prof., nevzat.unalan@ufuk.edu.tr, 0000-0002-7489-2852

\begin{abstract}
This study investigates user perception and resistance against change in the Hospital Information System (HIS) change. A quantitative approach with a survey was applied to determine perception and resistance ofogroups. The results were compared with each other: the percentage of innovators (32\%), the percentage of early adopters (21\%), the percentage of early majority (31\%), and the percentage of late majority (12\%), and the percentage of laggards (4\%). Acceptance differs due to financial reasons. The resistance differs according to the employees' status. IT developments, management supported security and privacy rules increase employee performance and acceptance. For resistance, there has been a significant difference feedback of employees is required, and functional needs reduce resistance. Hospitals need to use new and up-to-date information technology in order to serve effective patient care with valid standards.
\end{abstract}

Keywords : $\quad$ Change, Resistance, Health Information Systems

\section{Sağlık Bilgi Sistemi Değişim Direnci Değerlendirmesi}

$\ddot{O Z Z}$

Bu çalışma, Hastane Bilgi Sistemi (HBS) değişikliğinde kullanıcının algılamasını ve değişime karşı direnci araştırmaktadır. Grupların algı ve direncini belirlemek için bir anket ile nicel bir yaklaşım uygulanmıştır. Sonuçlar birbirleriyle karşılaştırılmıştır: yenilikçilerin yüzdesi (\%32), erken benimseyenlerin yüzdesi (\%21), erken çoğunluğun yüzdesi (\%31) ve geç çoğunluk yüzdesi (\%12) ve gecikme yüzdesi (\%4). Kabul, finansal nedenlerden dolayı farklllık gösterir. Direnç çalışanlarm durumuna göre değişir. BT gelişmeleri, yönetim destekli güvenlik ve gizlilik kuralları çalışanların performansını ve kabulünü artırır. Direnç için, çalışanlarm geribildirimi önemli bir fark olmuştur ve fonksiyonel ihtiyaçlar direnci azaltır. Hastanelerin geçerli standartlarda etkili hasta bakımı sunmak için yeni ve güncel bilgi teknolojilerini kullanması gerekmektedir.

Anahtar : : Değiş̧im, Direnç, Sağlık Bilgi Sistemleri

Kelimeler 


\section{INTRODUCTION}

The technology enables health information to be shared among patients, health professionals, and hospitals. Hospital Information Systems (HIS) has improved the capability of health institutions to manage health processes (Edelstein, 2017).

Information Technology (IT) affects societies and may cause resistance. Resistance means preserving the status-quo against any change (Kilian et al., 2003). The resistance needs the management of change. In this context "change" is an activity to get the best outcomes from the change process (Mulholland, 2008). It is about managing the changes which are parts or consequences of a particular organization's context and the type of change that is required (Backroad Connections Pty Ltd., 2004).

The aim of this study is to determine the resistances towards changes, to raise consciousness, and to determine status. The following questions were answered in this study:

-What is the user perception related with the "change management" process?

-What is the role of security and privacy issues for health professionals?

-What is the relationship of resistance factors for health professionals?

\section{CHANGE MANAGEMENT IN HOSPITAL INFORMATION SYSTEM}

Health Information Systems (HIS) "Change Management" phases, includes mechanisms awaking employees about necessity of a new system, taking their attention to that "raising awareness", expressing needs "raising desire", including how to implement changing "transparent inform", bringing manners and behaviors "earning creativity", making the change permanent "strengthening" (Kozak and Güçlü, 2003).

"Change Management" tools are communication which, makes employees emotions and thoughts clear; attending, which contributes decisions to make and participation to activities; motivation which, pushes and stirs; education which ensures necessity of information, thinking, interrogating, developing a talent, learning; leadership which drags 
employees and ensures purpose and management unity; senior management undertaking which claiming responsibility of changing activities (Kozak and Güçlü, 2003).

"Change Management" factors are demographic, technologic, economic, political, legal and competitive elements like treatment techniques being used in medical field, constantly renewed products and services, reduced product lives, rapidly changing technologies, high consumer renovation expectations, strengthening international strategic collaborations (Kozak and Güçlü, 2003).

Organizational changing process is first approached and studied by Kurt Lewin. Lewin examined changing in management by separating it into three different phases. These phases are Behavior Analysis which includes ice braking, launch, letting the already lived moment go. Shift Phase which includes change time of old styles and applications, starting and continuation. Refreeze Phase which includes making the change new and solid, freezing it (Kozak and Güçlü, 2003).

Hospital Information Systems (HIS) is an important element in patient care. HIS is an integration of clinical, administrative, and financial systems (Saluvan \& Ozonoff, 2018). HIS management phases include introducing employees about the necessity of a new system, raising awareness, expressing needs, implementing change, bringing earning creativity, and making the change permanent (Javanparast et al., 2017).

Change management does not have any specific approach for change. Frequently existing and potential blended models are used in the consultative and exploratory process. Change management is generally related to business management literature (Parlakkılıç, 2014). Awareness, Desire, Knowledge, Ability, and Reinforcement (ADKAR) is a change management model based on five steps (Shepherd et al., 2014):

- Awareness for change,

- Desire to participate and support the change,

- Knowledge to determine how to change,

- Ability to implement the change processes.

- Reinforcement to sustain the change post-implementation. 
In transformation, reviewing and analyzing to ensure the awareness change management has four basic strategies:

- Rational-Empirical Strategy: Appealing self-interest through incentives.

- Normative-Reductive Strategy: Adhere to social and cultural normalities, and through communication and education.

- Power-Coercive Strategy: Change strategy based on the use of authority, where necessary, and the imposition of penalties to comply.

- Environmental-Adaptive Strategy: Gradual transference from an old environment to a new one (Mackenzie-Robb, 2004).

The administration speed to apply technology is slower than the technological innovations (Banova, 2018). Since the recession is a barrier for technology implementation, change management must be as dynamic as the subject matters and domains of knowledge (Navid and Slusky, 2009). Therefore, institutions are seeking ways to harmonize their flexibility and effectiveness for change transition processes such as endings, the neutral zone, and beginnings (Brandon, 2007).

Endings: To give up the "old ways" and to have confidence and support by the move into their "neutral zone." Set the stage for positive new beginnings that can represent for people and the organization (Brandon, 2007).

The neutral zone: People making the transition to new state find themselves going through a four-phase change journey (Pugh, 2007):

- Denial,

- Resistance,

- Exploration,

- $\quad$ Commitment.

A well-designed change strategy ensures that people are supported through the early phases of denial and resistance with the "new way" that doesn't overwhelm them (Rick, 2013). 
Beginnings: When people are introduced to an innovation, Rogers (2003) suggests five distinct groups as innovators, early adopters, early majority, late majority, and laggards. Rogers (2003) estimated the percentage of each category is similar to the proportions found in a normal bell-curve and suggests that the innovators (2.5\% of adopters) go over the top first, followed by the early adopters (13.5\%), followed by the early majority $(34 \%)$, the late majority (34\%) and the laggards in the rear (16\%) (Rogers, 2003). The early adopters have the greatest influence in providing the success of the change long-term (Kaminski, 2011). They are the leaders who adopt new ideas early. And when they accept the change, the other groups of the majority can follow. The aim is to support and enable the process of change both for the people and organizations (Maguire and Honeyman, 2018).

\section{METHODS}

This study employs a quantitative approach as the purpose of the research is to determine health professionals change behaviors and resistance dimensions. The survey instrument was developed to gain as much information as possible for the health professionals (managers, professors, medical doctors, medical interns, nurses, laboratory assistants, and employees) in a state hospital in Turkey of which Hospital Information System was changed with a new one.

Question analysis of the Survey Instrument was performed by the experts working in the Medical Informatics Department of Gülhane Medical School in Ankara, Turkey. The survey questions were analyzed and updated. Thereafter the survey was pilot tested before used for data collection. The content and construct validity of the survey instrument was found high (Cronbach Alpha=0.93). Results of the analyses for each factor were reliable. The survey was available to participants by paper manually.

To measure change management, the study proposes two dimensions of change management drawn from the literature review: (1) User Perception; (2) Resistance. For each dimension, a group of statements was designed to measure a person's degree of agreement regarding specific issues that serve as indicators of change management. The Likert scale was used to gather responses with five ordered list, ranging from 1 being "strongly disagree", 2 "disagree", 3 "neutral", 4 "agree", and 5 "strongly agree". 
The questionnaire was divided into three sections: A, B, and C. Section A: Demographic-contains questions to collect demographic characteristics from the individuals including age, gender, education level, the institution they belong to, and their position in the institution. Section B: Communication issues-contains questions to collect individuals' communication and internet access information. Section C: Change Management dimensions-contains two variables of change management dimensions.

\section{RESULTS}

This research was done at a state hospital in Ankara, Turkey. Health professionals consisting of 176 employees, managers, professors, medical doctors, medical interns, nurses, and laboratory assistants participated in the survey. SPSS (22.0) was used to analyze the data obtained through the survey, as well as definitive statistical methods and the one-way ANOVA test was used to determine the information and skill points based on change perception the dimensions were evaluated, and results are as follows:

\section{User Perception}

Health professionals working in the hospital were categorized according to their perception in accepting change. Results of change acceptance are in Table 1 comparing with Rogers's findings.

Table 1. Change acceptance comparing with Rogers's findings

\begin{tabular}{|l|l|l|}
\hline Population & Rogers's Suggestion & Study Findings \\
\hline Innovators & $2.5 \%$ & $32 \%$ \\
\hline Early Adopters & $13.5 \%$ & $21 \%$ \\
\hline Early Majority & $34 \%$ & $31 \%$ \\
\hline Late Majority & $34 \%$ & $12 \%$ \\
\hline Laggards & $16 \%$ & $4 \%$ \\
\hline
\end{tabular}

To determine the adopters' differences, groups were compared with each other: the percentage of innovators (32\%), the percentage of early adopters $(21 \%)$, the percentage of early majority $(31 \%)$, and the percentage of late majority $(12 \%)$, and the percentage of 
laggards (4\%). These results show that the knowledge and skills of innovators are higher than other groups. It was seen that our findings differ from Rogers. This is estimated because of health professionals' readiness to accept change and the need for an effective HIS.

When health professionals' perceptions were analyzed, it was seen that the differences in user behaviors were based on the financial reason that is salary. The change perception affects information and skill points, hence the differences $(f=2.926, p<.05)$ among health professionals is reasonable due to different training and skill levels they have.

Table2. Anova results of change information and skill points based on change perception

\begin{tabular}{|l|l|l|l|l|l|l|}
\hline $\begin{array}{l}\text { Variance } \\
\text { Source }\end{array}$ & Square Sum & sd & $\begin{array}{l}\text { Square } \\
\text { Average }\end{array}$ & F & P. & Difference \\
\cline { 1 - 5 } Intergroup & 132,124 & 4 & 33,031 & 2,926 &, 023 & $1-2,1-3,1-4$, \\
\hline Intragroup & 1930,598 & 171 & 11,290 & & & \\
\hline Total & 2062,722 & 175 & & & & \\
\hline
\end{tabular}

Anova results presented in Table2 show us that change perception affects change information and skill points, that's why we can state that there are reasonable differences $(\mathrm{f}=$ $2,926, \mathrm{p}<.05)$ among change information and skill points of the groups. These results show that knowledge and skills of first members are higher.

\section{Resistance}

It has been tested whether the resistance factors differ according to the status of hospital employees. Statistically, there was no significant difference between motivation, future expectancy, and awareness factors. However, it was determined that there is a significant difference between the uncertainty factor and the statute $\left(X^{2}=42.04, p=0.04\right)$ as shown in Table 3. 
Table 3. Kruskal Wallis Test for Resistance Factors

\begin{tabular}{|l|l|l|}
\hline Factor & Chi-squared test $\left(\mathbf{X}^{2}\right)$ & $\mathbf{p}$ \\
\hline Motivation & 29.64 & 0.38 \\
\hline Future Expectations & 36.15 & 0.14 \\
\hline Uncertainty & 42.04 & 0.04 \\
\hline Awareness & 36.04 & 0.14 \\
\hline
\end{tabular}

It has been determined that the medical experts and doctors are the most knowledgeable about how the exchange will take place and that the nurses do not know how to change. Doctors were identified as having a low resistance sense and nurses as high resistance sense. When doctors are thought to have more knowledge of change, it is clear that a lower level of resistance is perceived. It was seen that the perceptions of nurses' resistance were due to the lack of highly demanded information for a new hospital information system.

\section{CONCLUSION}

Health information systems are affected by technological advancements, regulations, health politics, and quality assurances and with integration to other health systems. They are bound to be changed continuously. When employees support a change initiative, with participation as soon as possible and a contribution to the change process on their own initiative, it gets easier.

In the study, when health professionals' perceptions were analyzed, it was seen that the differences were based on human capital. And the results also show that the knowledge and skills of professionals are higher for health professionals who accept innovations than other health professionals.

The success of change management lies on the human side of the change rather than setting up modern technical systems. Change must be in the management cultures and be embraced by all employees. Information systems' new developments increase user satisfaction. Compliance to security and privacy rules should be strongly supported by 
management and employees. It was seen that resistance factors differ according to the status of hospital employees.

\section{REFERENCES}

Backroad Connections Pty Ltd. (2004). Approaches to Change Management for Flexible Learning (Version 1.02),. Australian Flexible Learning Framework Quick Guides series, Australian National Training Authority.

Banova B. (2018). The impact of technology on healthcare. American Institute of Medical Sciences. http://www.aimseducation.edu/blog/the-impact-of-technology-on-healthcare/ (accesed January 2020)

Brandon B. (2007) The eLearning Guild's Handbook of e-learning Strategy, The eLearning Guild. Street, Suite 200 Santa Rosa, CA 95404

Edelstein P. (2017). Top trends in health information \& communications technology for 2017, http://www.elsevier.com/connect/top-trends-in-health-information-and-communicationstechnology-for-2017 (accesed December 2019)

Javanparast S, Maddern J, Baum F, et al. (2017). Change management in an environment of ongoing primary health care system reform: A case study of Australian primary health care services. Int J Health Plann Mgmt. https://doi.org/10.1002/hpm.2413.

Kaminski, J. (2011). Diffusion of Innovation Theory Canadian Journal of Nursing Informatics, 6(2). Available at: http://cjni.net/journal/?p=1444 (accesed May 2019).

Kilian M. Bennebroek Gravenhorst. (2003). A Different View on Resistance to Change", Paper delivered at the "Power Dynamics and Organizational Change IV" Symposium at the 11th EAWOP Conference in Lisbon, Portugal, 14-17 May 2003

Kozak, M.A., Güçlü H. (2003). Turizm İşletmelerinde Değişim Yönetimi Üzerine Kavramsal Bir İnceleme", Endüstri İlişkileri ve İnsan Kaynakları Dergisi.

Mackenzie-Robb. LE-(2004.).learningand Change Management - The Challenge.

Maguire, D and Honeyman, M. (2018). Digital change in health and social care Digital health and care congress July 2018.

http://www.kingsfund.org.uk/sites/default/files/20180*6/Summary_digital_change_ health_care_Kings_Fund_June_2018.pdf (accesed May 2019). 
Mulholland B. (2008). Critical Change Management Models to Evolve and Survive http://www.process.st/change-management-models/ (accesed April 2019)

Slusky, L., \& Navid, P. (2009). Challenges of Change Management in E-learning (Distance Learning), Encyclopedia of Distance Learning, Second Edition. (4 Volumes)

Parlakkılıç, A. (2014). Change Management in Transition To E-learning System. Qualitative and Quantitative Methods in Libraries (QQML) 3:637 -651,

Pugh, L. (2007). “Change Management in Information Services. Asghate Publishing Limited, Aldershot

Rick T. (2013). Change Is Not The Problem - Resistance To Change Is The Problem http://www.torbenrick.eu/blog/change-management/change-is-not-the-problem-resistance-tochange-is-the-problem/ (accesed March 2020)

Rogers, E. M. (2003). Diffusion of innovations. New York: Free Press

Saluvan, M., \& Ozonoff. (2018). A Functionality of hospital information systems: results from a survey of quality directors at Turkish hospitals. BMC medical informatics and decision making, 18(1), 6. DOI:10.1186/s12911-018-0581-2

Shepherd, Mary Lohse et al. (2014). Using the Awareness, Desire, Knowledge, Ability, Reinforcement Model to build a shared governance culture. http://www.vantaggiolearn.com/White\%20papers/VantaggioCM.pdf (accesed March 2020). 